\title{
Front Matter: Volume 11697
}

, "Front Matter: Volume 11697," Proc. SPIE 11697, MOEMS and Miniaturized Systems XX, 1169701 (27 April 2021); doi: 10.1117/12.2596726

SPIE. Event: SPIE OPTO, 2021, Online Only 


\section{PROCEEDINGS OF SPIE}

\section{MOEMS and Miniaturized Systems XX}

Hans Zappe

Wibool Piyawattanametha

Yong-Hwa Park

Editors

6-11 March 2021

Online Only, United States

Cosponsored by

Mirrorcle Technologies, Inc. (United States)

Published by

SPIE

Volume 11697 
The papers in this volume were part of the technical conference cited on the cover and title page. Papers were selected and subject to review by the editors and conference program committee. Some conference presentations may not be available for publication. Additional papers and presentation recordings may be available online in the SPIE Digital Library at SPIEDigitalLibrary.org.

The papers reflect the work and thoughts of the authors and are published herein as submitted. The publisher is not responsible for the validity of the information or for any outcomes resulting from reliance thereon.

Please use the following format to cite material from these proceedings:

Author(s), "Title of Paper," in MOEMS and Miniaturized Systems XX, edited by Hans Zappe, Wibool Piyawattanametha, Yong-Hwa Park, Proc. of SPIE 11697, Seven-digit Article CID Number (DD/MM/YYYY); (DOI URL).

ISSN: 0277-786X

ISSN: 1996-756X (electronic)

ISBN: 9781510642294

ISBN: 9781510642300 (electronic)

Published by

SPIE

P.O. Box 10, Bellingham, Washington 98227-0010 USA

Telephone +13606763290 (Pacific Time)

SPIE.org

Copyright @ 2021 Society of Photo-Optical Instrumentation Engineers (SPIE).

Copying of material in this book for internal or personal use, or for the internal or personal use of specific clients, beyond the fair use provisions granted by the U.S. Copyright Law is authorized by SPIE subject to payment of fees. To obtain permission to use and share articles in this volume, visit Copyright Clearance Center at copyright.com. Other copying for republication, resale, advertising or promotion, or any form of systematic or multiple reproduction of any material in this book is prohibited except with permission in writing from the publisher.

Printed in the United States of America by Curran Associates, Inc., under license from SPIE.

Publication of record for individual papers is online in the SPIE Digital Library.

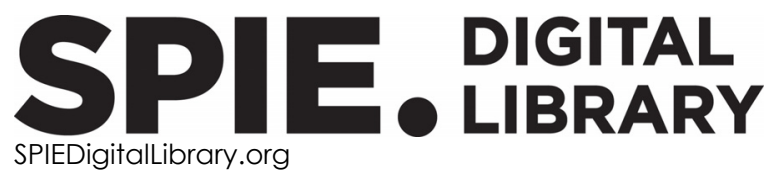

Paper Numbering: A unique citation identifier (CID) number is assigned to each article in the Proceedings of SPIE at the time of publication. Utilization of CIDs allows articles to be fully citable as soon as they are published online, and connects the same identifier to all online and print versions of the publication. SPIE uses a seven-digit CID article numbering system structured as follows:

- The first five digits correspond to the SPIE volume number.

- The last two digits indicate publication order within the volume using a Base 36 numbering system employing both numerals and letters. These two-number sets start with 00, 01, 02, 03, 04, 05, 06, 07, 08, 09, 0A, OB ... 0Z, followed by 10-1Z, 20-2Z, etc. The CID Number appears on each page of the manuscript. 


\section{Contents}

MICRO-MIRRORS I

1169703 Photo-controlled deformable mirror for wavefront shaping (Invited Paper) [11697-1]

1169704 A 2D circular-scanning piezoelectric MEMS mirror for laser material processing [11697-2]

1169706 A novel closed-loop architecture for accurate micromirror trajectory control in linear scanning MEMS-based projectors [11697-4]

$1169707 \quad$ Large aperture MEMS mirror with integrated piezoelectric actuator [1 1697-5]

MICRO-MIRRORS II

1169708 Quasi-static PZT actuated MEMS mirror with 4x3 $\mathrm{mm}^{2}$ reflective area and high robustness (Invited Paper) [1 1697-6]

1169709 Innovative ECDL design based on a resonant MEMS scanner for ultra-fast tuning in the MIR range [1 1697-7]

11697 OA A two-axis water-immersible micro scanning mirror (WIMSM) using torsional and bending polymer hinges (Best Student Paper Award) [1 1697-8]

11697 OB Wide-angle wide-spectral range IMI plasmonic MEMS mirror in the MIR for spectroscopic gas sensing applications [1 1697-9]

11697 OC Multiple MEMS mirrors synchronization techniques, modeling, and applications [11697-10]

LIDAR I

11697 OD Wide angle LiDAR demonstrator based on a resonantly operated ID MEMS mirror capable of scanning $180^{\circ}$ (Invited Paper, Best Paper Award) [11697-11]

11697 OF A design and manufacturing platform for AIScN based highly linear quasi-static MEMS mirrors with large optical apertures [1 1697-13]

11697 OG Efficient driver and high accuracy sense ASICs for piezoelectric micro-mirrors [11697-14]

LIDAR II

$11697 \mathrm{OH} \quad$ Amplitude-modulated continuous wave scanning LIDAR based on parallel phasedemodulation (Invited Paper) [11697-15] 
11697 Ol Beam-steering MOEMS system based on a resonant piezoMEMS mirror and a phase-locked loop controller [11697-16]

NOVEL OPTICAL COMPONENTS I

11697 OM Photonic crystal MEMS emitter for chemical gas sensing [1 1697-20]

11697 ON CMOS compatible MEMS pyroelectric infrared detectors: from AIN to SCAIN [11697-21]

$1169700 \quad$ Tunable optical filters with hybrid plasmonic-dielectric thin-films for fluorescence sensing [1 1 697-22]

NOVEL OPTICAL COMPONENTS II

11697 OP Smart slit assembly employing continuously tunable MEMS shutter (Invited Paper) [11697-23]

$116970 Q \quad$ Compact and innovative laser beam steering optical engine for smart glasses applications [1 1697-24]

11697 OR Compact detector unit based on the butterfly assembly for trace gas analysis [11697-25]

IMAGING

11697 OV Challenges of monolithic MEMS-on-CMOS integration for spatial light modulators [11697-29]

POSTER SESSION

1169714 MEMS-based polarized FTIR spectrometer for polymer quality control [1 1697-38]

$1169715 \quad$ Electro-mechanical validation of a resonant MEMS mirror with PZT actuation and PZR sensing [1 1697-39]

$1169716 \quad$ Modeling and experimental verification of the impact of noise sources on projection accuracy of MEMS linear micromirrors for raster scanning applications [1 1697-40]

1169717 On-chip structure for optofluidic sensing using stable Fabry-Pérot resonator [11697-41]

1169718 A 2D electrothermal micromirror with feedback based on Hall-effect of piezoresistive sensors [1 1697-42] 